\title{
A Marxist-Feminist Study of Social Inequality in Arab and American Literature
}

\author{
Sarah Abdul Salam Naeem \\ Shatt Al-Arab University College, Basra, Iraq
}

\begin{abstract}
Academic scholars over the last few decades, in feminist studies, sociology, and other fields of study in human science have paid enormous attention to gender issues mainly the so called "gender identity". The present paper will in the literary field extend the debateable subject by investigating the social inequalities linked to gender and class in the Arab and American societies. Marxist-feminist criticism will be the method of analysis according to which gender is a socially developed ideology that is reflected in the societal and cultural practices. This paper will shed light on the Arab-American literature with special reference to Ahlam Mostaghanemi's The Black Fits you and Gillian Flynn’s Gone Girl to project the social issues of gender equality and gender identity.

Keywords: social inequality, gender identity, class, Arab-American literature
\end{abstract}

\section{Introduction}

Gender and class are the two great powers by which the society is formed. According to George Ritzer (2003), the class is a group of people who are in the same economic and social status that is different from other groups, while gender refers to the social constructed ideologies and norms that can determine men and women's behavior and actions (Kangas, Haider, \& Fraser, 2014, p. 4). This concept of gender is very important to be understood because it is a means of achieving the equality between men and women regardless to their biological differences. In other words, women can get their rights if they live in a society that never let the biological differences determine their roles. In this way, the gap of discrimination between men and women will be limited. As a result, modern feminist literature concentrates profoundly on the class distinction and gender inequality, and it also reflects the society positively when men and women reach their equality, socially and economically. The reason behind the variation of women's roles among Eastern and Western society is that their roles depend on social, political, cultural, economic, and religious factors. In most of Mostaghanemi and Flynn's writings, the focus is on the ability of women to be independent and tries to show the bad impact of the class discrimination on the society. Even their words are feminist and call for the equality either directly or ironically. The author sheds light on those two writers because of the studies on their writings are very rare and scarce.

\section{Marxism}

Tomasz Helemejko (2014) stated that the most famous economist and philosopher for the creation of the thought of Marxism and for the improvement of the idea of the class struggle is Marx. The historical

Sarah Abdul Salam Naeem, B.A. Student, Shatt Al-Arab University College, Basra, Iraq. 
materialism and the importance of means of production in the way the history was formed can be found in his Communist Manifesto. He points out that the economic basis of society has an essential role in social struggles as a whole as well as the psychology of the people within it. In one of his writings, he declares that the proletarian revolution is the result of the constant class struggle and in that way the proletarian class will win and non-class society will spread.

According to Lutfi Hamadi (2017), the works of literature or art can be viewed by Marxism as the products of historical forces that can be studied by looking at the material conditions in which they are produced. Generally, the focuses of this theory are on the conflict between the dominant and repressed classes in any given age. In other words, this assumption that literature must be understood in relation to historical and social reality of a certain society is the basic start of literary theory.

\section{Feminism}

Frank (2018) stated that feminism can be defined as the belief that men and women should be equal in all opportunities, treatment, respect, and social rights. People who observe social inequality based on gender and those who try to stop it are called "feminists". They point out that men have received more opportunities than women in most cultures throughout history.

Feminist criticism has many stands, but most critics have general aspects in common. Those critics hope to change the societies through changing the literature that people read. They reject the analysis of male/female power structure that makes woman appear as inferior. Moreover, they aim to repeal limiting stereotypes of women, and seek to destroy the patriarchal system that creates prejudices against women. Therefore, those aims can be achieved by feminist critics through rediscovering forgotten texts by women, re-evaluating other texts, and examining the cultural contexts in which works were produced (Dobie, 2011, p. 10).

According to Frank (2018), there are different types of feminism, including radical feminism, socialist feminism, cultural feminism, and liberal feminism:

Radical feminism: It is the movement that seeks to find a technology that will allow babies to be grown outside of woman's body in order to provide more equality between man and woman. The aim of this movement is to eliminate the concept of gender entirely.

Socialist feminism: Destroying capitalism through a socialist reformation of the economy is the basic aim of this movement. It believes that capitalism supports the class because men who have power and money will share them with other men. In that case, women will give fewer opportunities and will be under the control of men.

Cultural feminism: According to Kristina Woolf (2007), cultural feminism aims to understand the social locations of women by focusing on gender differences between man and woman. It seeks to liberate women through individual change, creation of women-centered culture, and redefinition of femininity and masculinity. The basic understandings of male and female differences are considered as the foundation of women's subordination in society by this movement.

Liberal feminism: As Judith Lorber (1997) declared, liberal feminism states that men and women are not different since gender differences are not based on biology. As a result, women should be equal to men in laws. In addition, their rights, works, and educational opportunities should be the same as of men. 


\section{Marxist-Feminist Criticism}

Since the later part of the 19th century, the Marxist theory has been used as a guiding principle for women's liberation. August Bebel has been inspired by Marx formulation about the development of productive forces leading towards freedom from necessity. As a result, he wrote a book entitled Women and Socialism. The development of kitchen equipment and the setting up of canteens at the work place were linked with women getting rid of unpleasant and time consuming work which restricted them to the necessity of reproduction in that treaties. Bebel also thought that socialism would create the possibility of women's freedom to participate in public life by releasing the forces of production in that most private area which is the kitchen. He debated very deeply that all social dependence and oppression were the result of economic dependence or lack of independent property rights. In his history and when patriarchy was existed, he concentrated on the role of force and violence that was established through arbitrary laws and religious and cultural norms. Moreover, he argued that the decline of fertility is the result of the result of women's improvement by defending women's capacities and position. Furthermore, advanced feminist tradition inaugurated by William Thompson and Anna Wheeler. The excellent representation of Marxist feminist attempt to reinterpret Marxism to include woman's work of re-production as a part of production system is found in the writings of Mcdonough and Harrisons. In the German Ideology, those two authors find that Marx concentrated on three moments of human's production activity which are the production of human needs, production of new needs, and propagation of family. As a result, they criticize Marx for changing his earlier trend into sexist interpretation in later writings. ${ }^{1}$

Nancy Hartsock (1983) made an effort leading Marxism to be more inclusive of differences in the activities of men and women, that by which the basis of their identities will be formed. She assures that any theory based on the male standpoint (wage of male labor) would stay partial because it would not take into consideration the experience of women's production activity that is basically based on the unity and connectedness of humans and nature. Her point of view is that men will not be able to create a theory of the whole if they do not participate in the activity of child rearing. In addition, she claims that male experience is inverted by female's one that forms a basis on which one can expose abstract masculinity as both partial and fundamentally perverse. Besides, she encourages using the term "sexual division of labor" rather than "gender division of labor" in order not to let the bodily aspects awareness of human existence to be evaporated.

\section{Class}

The lives of most women are still bounded by prejudice and social oppression although there are many international conferences and "universal declarations" that aim at achieving the equality between men and women. Male supremacy is compelled very considerably from one society to another and among social classes within each society. Everywhere, men are taught to consider themselves as superior. In the other hand, women are taught to accept the inferiority. Some women have power and privilege of access but not as that of men. According to the United Nations, women perform two-thirds of the world's work, and produce about 45 percent of the world's food, but they receive no more than 10 percent of the property.

Tomasz Helemejko (2014) stated that Marx admits he was not the founder of the concept that society is divided into classes and he did not even notice the conflict between them. Marx shows the real basis of class division and consequences of this state as a contribution of the idea of the class and its struggles. In addition,

\footnotetext{
${ }^{1}$ See http://shodhganga.inflibnet.ac.in/bitstream/10603/109568/7/07_chapter\%203.pdf
} 
Marx indicated that in 18th century and because of the differences between propertied and non-propertied classes, they began to split and polarize into two groups: oppressors and oppressed.

\section{Gender}

According to Shuvo Ghosh (2015), gender identity is a term that refers to a personal conception of oneself as male or female (or seldom, both or neither). There is a strong relationship between this concept and the concept of gender role which is more concerned with outward manifestations of personality and reflects the gender identity. In other words, the combination of inheritance and environmental factors form gender identity while the observable factors, such as behavior and appearance form the gender role. As a result, masculinity is a term which refers to a person who considers himself as a male, but his gender role is male only if he demonstrates typically male characteristics in behavior, dress, and/or mannerisms.

As a social problem, gender inequality has received special attention from policy-makers, academicians, and welfare activities. Many debates and awareness are created by the socio-political movement which is feminism. Furthermore, women's distresses on both public and private spheres are highlighted by feminists. So, it is clear that gender inequality is a serious issue which needs urgent and great regard. And because capitalism is responsible for the gender inequality and power gap between men and women, the capitalists should try to minimize that gap as a part of their duty by being more careful in their dealing with women's rights if they asked about gender/women issue and thus the basic rights of women will be saved and supported (Hossain, Nik Ahmad, \& Siraj, 2016, p. 15).

Women are usually provided with low paid jobs because men at the workplace consider them as less capable and less productive. They also can rarely be promoted to the top position of their jobs because men consider working under the women bosses as something disgraceful. Moreover, women have to play multiple stressful roles and to make a balance between both work life and family life (p. 18).

\section{Gone Girl Analysis}

The feminist's features and the effect of the economic status are very clear and prominent in Gillian Flynn's Gone Girl. The author portraits the concept of gender by using a bold girl in order to show what is inside the cover of this creature made by the society. She also embodies the impact of the financial state on people and in particular on married people. Gender stereotypes and their negative consequences are also explored profoundly. The story involves events about Amy's life and her relationship with her husband.

Amy pretends that she is an amazing girl whom all men dream of her in order to make Nick fall in love with her. Nick, who represents many other men, also tries to appear as an ideal man the way that he can get a girl whom she wants nothing of life but pleasing him. So, it is clear that if the woman wants to marry whom she likes, she should be cool and ideal instead of being herself.

He didn’t love me, me. Nick loved a girl who doesn’t exist. (Flynn, 2012, p. 222)

Cool girls never get angry; they only smile in a chagrined, loving manner and let their men do whatever they want. (Ibid.)

pathetic:

They're "Cool Girls are even more

not even pretending to be the friend, coworkers,

woman they want to be, they're pretending

to be the woman a man wants them to be”. (Ibid.) 
After their marriage, Amy gets bored of women's stereotypes that she follows, and the character of the real Amy which is away from idealism starts to appear. Nick could not accept the idea that his wife is intelligent, well-educated, and strong but instead, he likes to see her as inferior who depends on him emotionally and socially. As a result, he abuses her and makes an affair with one of his students. Besides, as he throws her forcefully to the floor, she no longer feels save with him.

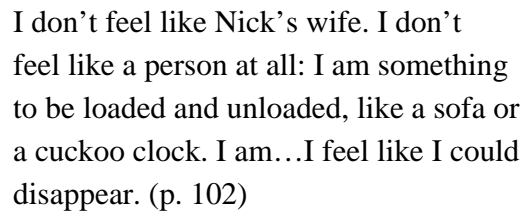

This patriarchy repression motives her to create a plan that frames her husband for her murderer. The norms and obstacles of the society that limit women's freedom lead Amy to be aggressive and villain. She even thinks to kill herself to prove Nick's guilt but she gets rid of this idea the moment she becomes "herself".

He took away chunks of me with blasé swipes: my independence, my pride, my esteem. I gave, and he took and took. He Giving Treed me out of existence. (p. 238)

He killed my soul, which should be a crime. Actually it is a crime. According to me, at least.

every morning you have to wake up

and be you. (p. 415)

Moreover, when Amy meets her old boyfriend, Desi Collins, to ask him for help, she finds that he is also pleased with the idea of having a control over women and making them feel like prisoners. Obviously, Amy has been enforced to kill him in order to get back her freedom and dignity.

Nick and Amy's marriage also has influenced by economic problems which plays a vital role in their normal life. The subdivision they live in their relationship is the outcome of losing their jobs. What is worse is that they have to move to Missouri to take care of Nick's sick mother. This case leads them to live in a very huge gap of financial. As they live in a capitalist city, even the unemployed men are seen as potentially connected to Amy's disappearance.

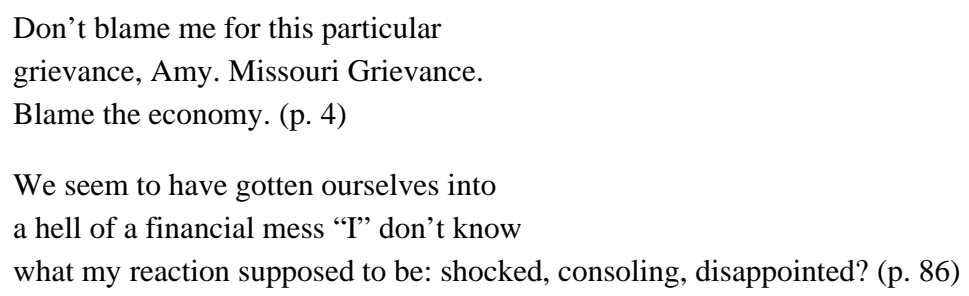

Amy spends a year to develop her plan, to write an unreal diary against Nick and to save enough money to disappear. All these things reflect her cleverness and shrewdness. At the end, she decides to enforce her husband to live with her (the real Amy) by means of pregnancy.

Something bad was about to happen.

My wife was being clever again. (p. 338)

To sum up, the force of capitalism which stands against their dreams of perfect life influences Amy and Nick's relationship negatively. In other words, most of the tensions between them are due to the deterioration of their living conditions that lead them to an unknown future. Flynn provides us evidence that to be a villain, 
aggressive, violent, and other attributes which denote rebellion is not only restricted to men. That is to say, both man and woman have an evil side regardless to their biological composition. Lack of equality, the prejudice to men, and women's stereotypes that are reinforced by the society drive Amy to commit a crime. Amy avenges from those men who want her to make endless compromises and to live under their control and mercy as well. Flynn frames her as a strong, independent, and brave person who decides how to live her own life confidently.

\section{The Black Fits You Analysis}

Ahlam Mosteghanemi's ${ }^{2}$ The Black Fits You has clear feminine features since women are encouraged to love life and to be independent. Ahlam portraits how patriarchal system is rooted in the society and how that system affects women. Besides, she sheds light on those men who consider women as an inferior figure that can be easily bought and sold.

Halah is an epitome for a strong woman who cares for her future. Although she suffers a lot after her father and brother's death, she tries to prove her strength and conquer the difficult circumstances gamely. By using peaceful tools which are songs and music, she revenges for all people who were killed by terrorism. And because girls are not allowed to sing in Algeria, she moves to Syria in order to shout against the dark customs and traditions.

Who sings, could defeat his fear. He is a “free man!” (Mostaghanemi, 2012, p. 76)

Who has nothing but only his vocal cords,

is able to wrap the cord around hismurderer's neck.

It is enough he sings, nopower can do anything against who decided toface death by singing. (Ibid.)

Mosteghanemi also adopted the idea of class within society by presenting to us an aristocratic man whom Halah meets. That man, who named by Talal, is married and he has two daughters. However, he still feels that he is in need for a boy to get the inheritance. By having a good wealth, he thinks that he can get whatever he wants including women. When he sees Halah in a TV program, he tries to draw her attention and enters her world by means of money. He reserves the whole hall just to sit on one seat and listen to her singing alone. In other words, her voice can be bought easily by money.

Is it because of that? Wealthy people need others to help them in that exclusive waste of money, fearing that money destroys them if they were alone with him. (p. 270)

At the beginning, the woman is depicted as a sensitive figure that is controlled by man. Halah is blind in her relationship with Talal who always tries to prevent her from singing. And also he always tells her that the black fits her for the sake of possession.

He likes to see the fluctuation of women's attitude and their stupid behavior in front of the fake signs of love. (p. 72)

I will always know you as long as

the black is your color.. I mean

our color. (p. 298)

\footnotetext{
${ }^{2}$ See https://www.thefamouspeople.com/profiles/ahlam-mosteghanemi-5992.php.
} 
On the other hand, when Halah discovers his intentions, she wears the blue instead of the black and leaves him.

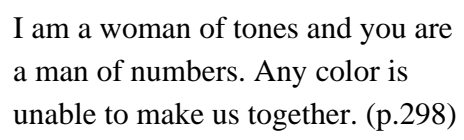

Finally, Halah defends her rights and stands against the norms, customs, and system of society. She sings for freedom and life. By wearing the blue color instead of the black, she defeats the blackness and sadness of living and starts another life in order to achieve her great goals. Mosteghanemi tries to portrait woman's image at that period and shows us that woman represents a complete figure that can resist and live independently.

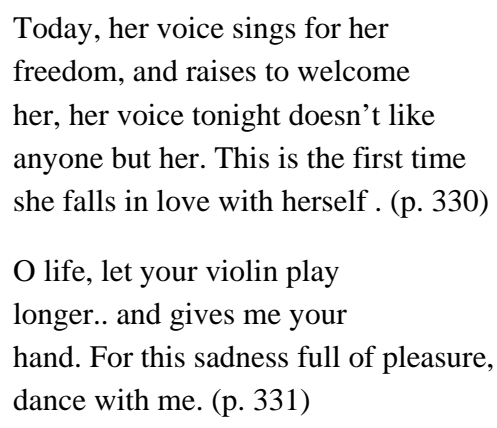

\section{Conclusion}

Mostaghanemi and Flynn have both granted us vital evidence about the importance of economic status and how it directly influences people's life. Mostaghanemi’s The Black Fits You calls for women's independency, encourages them to live their life peacefully and help them to stand and sing for her dreams and future away from men's domination. It incites all women to get rid of patriarchy obstacles the society imposed. In contrast, the depiction of women in Flynn's Gone Girl is rather different. It shows that women have the right to be evil and this point serve as a negation against women's idealism that is supposed to be found in all womanhood. Besides, women are represented in the way that they can take the role of men and to live their life the way they like out of men's control.

\section{References}

Dobie, A. B. (2011). Theory into practice: An introduction to literary criticism. Wadsworth Cengage Learning. Retrieved fromhttp://elibrary.bsu.az/books_400/N_152.pdf

Flyn, Gillian. (2012). Gone girl. United States: Crown Publishing Group.

Frank, T. (2018). Feminism types and definitions: Liberal, socialist, culture \& radical.Retrievedfrom https://study.com/academy/lesson/feminism-types-and-definitions-liberal-socialist-culture-radical.html

Ghosh, S. (2015). Gender identity. Retrievedfrom https://emedicine.medscape.com/article/917990-overview

George, Ritzer. (2003). Rethinking Globalization: Glocalization/Grobalization and Something/Nothing. Sage Journals. University of Maryland.

Helemejko, T. (2014). The concept of Marxism.Retrievedfrom http://www.repozytorium.uni.wroc.pl/Content/40318/002.pdf

Hossain, D. M., Ahmad, N. N. N., \& Siraj, S. A. (2016). Marxist feminist perspective of corporate gender disclosures. Asian Journal of Accounting and Governance, 7, 11-24.

Kangas, A., Haider, H., and Fraser, E. (2014). Gender: Topic Guide. Revised edition with E. Browne. Birmingham: GSDRC, University of Birmingham, UK. 
International Bolshevik Tendency (IBT). (1917). Marxism, feminism \& women's liberation. Retrieved 1/5/2019 from http://www.bolshevik.org/1917/no19fem.pdf

Lorber, J. (1997). The variety of feminisms and their contributions to gender equality. Oldenburg: Bibliotheks- und Informationssystem der Univ. Oldenburg.

Lutfi, H. (2017).The concept of ideology in Marxist literary criticism. European Scientific Journal (ESJ), 13(20), 154.

Mostaghanemi, A. (2012). The black fits you. Lebanon: Hachette-Antoine.

Nancy, Hartsock. (1983). Money, Sex, and Power: Toward A Feminist Historical Materialism. London, Longman.

Wolff, K. (2007). Cultural feminism. Retrieved from https://doi.org/10.1002/9781405165518.wbeosc174 